\title{
New late Smithian (Early Triassic) ammonoids from the Lusitaniadalen Member, Vikinghøgda Formation, Svalbard
}

\author{
Veronica Piazza 1 , Øyvind Hammer ${ }^{2} \&$ Romain Jattiot ${ }^{3,4}$
}

\author{
${ }^{1}$ Museum für Naturkunde, Leibniz-Institut für Evolutions- und Biodiversitätsforschung, Invalidenstr. 43, 10115 Berlin, Germany. \\ ${ }^{2}$ Naturhistorisk Museum, Universitetet i Oslo, P.O. Box 1172 Blindern, 0318 Oslo, Norway. \\ ${ }^{3}$ Paläontologisches Institut der Universität Zürich, Karl Schmid-Strasse 4, 8006, Zürich, Switzerland. \\ ${ }^{4}$ UMR CNRS 6282 Biogeosciences, Université de Bourgogne Franche-Comté, 6 Boulevard Gabriel, 21000, Dijon, France. \\ E-mail corresponding author (Veronica Piazza):Veronica.Piazza@mfn-berlin.de
}

\begin{abstract}
A single carbonate concretion from the uppermost Lusitaniadalen Member ('Fish Niveau', Vikinghøgda Formation) at Stensiöfjellet, Spitsbergen, contains a fairly rich assemblage of late Smithian (Early Triassic, Olenekian) ammonoids. The main species identified are Wasatchites tridentinus Spath, 1934, Wasatchites cf. distractus (Waagen, 1895), Anasibirites kingianus (Waagen, 1895), Arctoprionites nodosus (Frebold, 1930), Arctoprionites resseri (Mathews, 1929) and Xenoceltites subevolutus Spath, 1930. Two taxa are here discussed: Prionitid sp. and Arctoceras erebori sp. nov. The assemblage provides new information about the Early Triassic biostratigraphy and palaeogeography of the Boreal Realm. The composition of the Spitsbergen fauna is in good agreement with other assemblages within and outside the Boreal Realm and essentially comprises cosmopolitan taxa. Only Arctoceras erebori sp. nov. and Prionitid sp. are as yet restricted to Spitsbergen. The newly reported occurrence of low paleolatitude taxa from Spitsbergen strengthens the cosmopolitan distribution of ammonoids during late Smithian time, thus improving existing correlation.
\end{abstract}

Keywords: Ammonoid biostratigraphy, Tardus Zone, Smithian, Prionitidae, Svalbard, Boreal Realm

Received 4. May 2017 / Accepted 21. June 2017 / Published online 7. August 2017

\section{Introduction}

A growing interest is focused on the usefulness of Early to Middle Triassic ammonoids of the Boreal Realm as high-resolution biostratigraphic markers, which in part benefit the increased petroleum exploration activity in the region and its need for accurate biochronological correlation. A revision of ammonoid taxonomy, biostratigraphy and palaeobiogeography of the Boreal Triassic is therefore required. The present paper provides new interpretations of a late Smithian fauna from Spitsbergen, and a new taxon is presented.

\section{Triassic palaeogeographic setting}

During the Mesozoic, the Svalbardian faunas belonged, in a broader palaeobiogeographic perspective, to the Boreal Realm, which also included present-day Greenland, Arctic Canada (Sverdrup Basin) and Russia (Siberia). These localities (Fig. 1) were located along the northern margin of Pangaea, making intra-Boreal correlations possible, while British Columbia (Canada) was located at mid-palaeolatitudes (Dagys \& Weitschat, 1993a; Tozer, 1994; Vigran et al., 2014). 


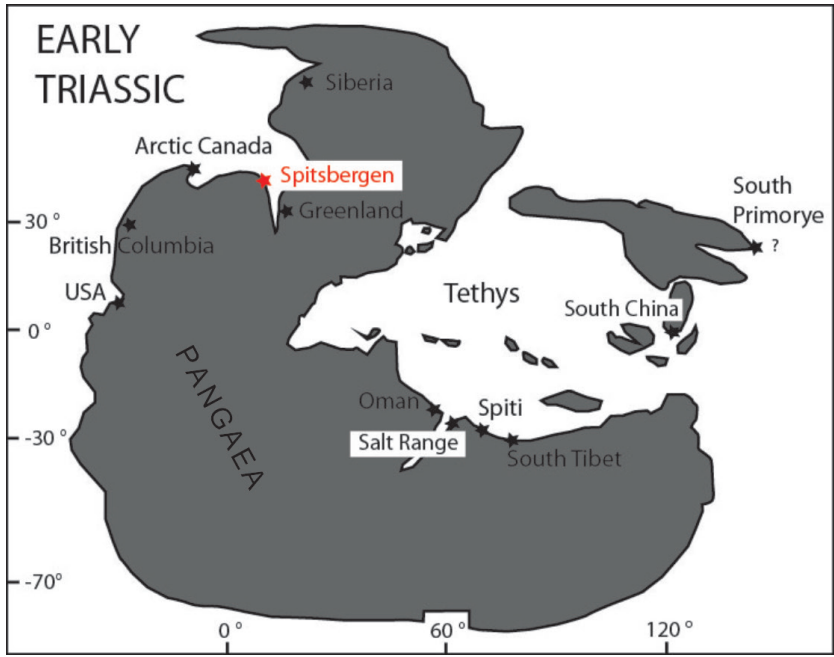

Figure 1. Early Triassic palaeogeographic setting. Spitsbergen (red star) as well as other important localities (black stars) is shown (modified from Brühwiler et al., 2010, fig. 1).

Boreal Early Triassic ammonoid faunas were characterised mainly by low alpha (= local) diversity, significant intraspecific variation (e.g., Hammer \& Bucher, 2005; Weitschat, 2008) and high endemism (Tozer, 1982; Brayard et al., 2006). The Early Triassic Boreal Realm can be divided into western (Sverdrup Basin) and eastern (Siberian) provinces according to taxonomic differences of the ammonoid assemblages. Svalbard was located somewhat in between, presenting affinities to both of these provinces, although such affinities were not constant. Based on these intermediate affiliations, the establishment of a Svalbardian province was proposed by Weitschat \& Dagys (1989).

\section{Smithian biostratigraphy}

Svalbardian Triassic fossils have been known for more than 140 years (e.g., Öberg, 1877). Smithian fossils were originally studied by Spath $(1921,1934)$ and Frebold (1930). However, it was Tozer \& Parker (1968) who subdivided the Smithian in Svalbard into the lower Romunderi Zone and the upper Tardus Zone in an attempt at a modern ammonoid zonation. Subsequent contributions were provided by Korčinskaja (e.g., 1970, 1973) and Weitschat (e.g., Weitschat \& Lehmann, 1978; Weitschat \& Dagys, 1989; Dagys \& Weitschat, 1993a). An overview of the most important ammonoid biostratigraphic divisions of the Smithian of Svalbard is shown in Table 1.

The Tardus Zone defines the late Smithian in the Boreal Realm, and is characterised by cosmopolitan prionitids and xenoceltitids (e.g., Xenoceltites Spath, 1930); (Brühwiler et al., 2010). The late Smithian faunas of Svalbard are closely related to the faunas of the Sverdrup

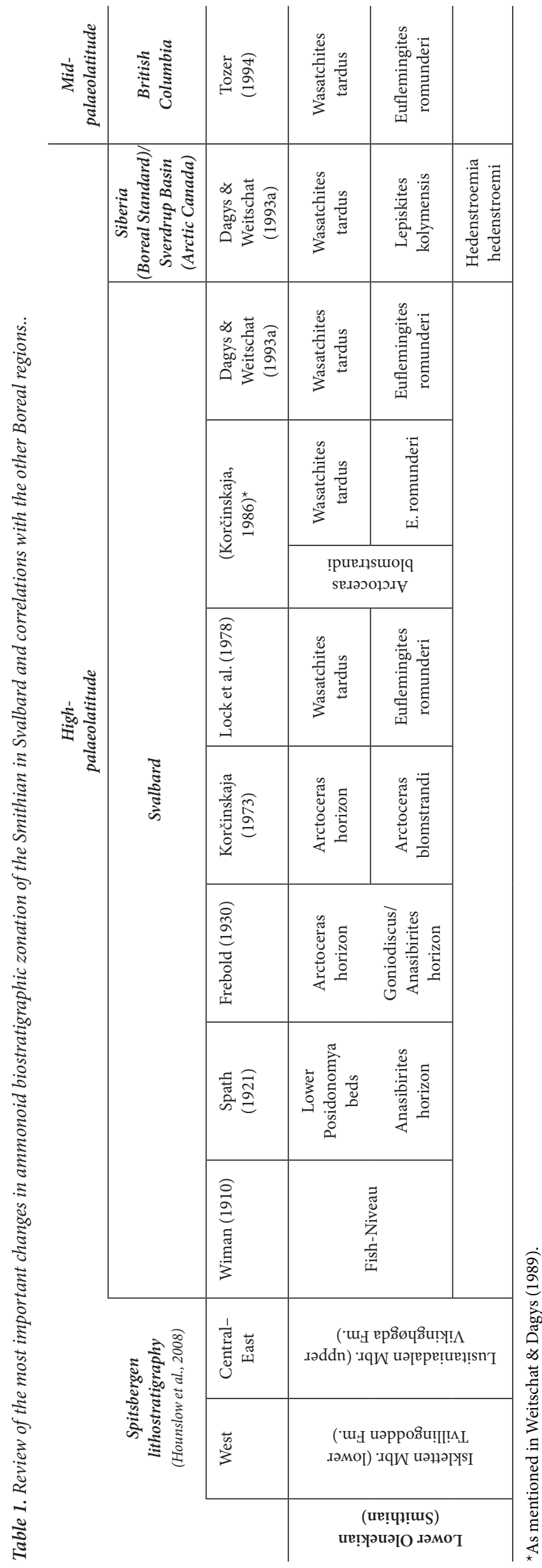


Basin (Weitschat \& Lehmann, 1978). The Boreal Tardus Zone can be correlated with the stratigraphic units containing Wasatchites Mathews, 1929, Anasibirites Mojsisovics, 1896 and Xenoceltites in many Tethyan localities (e.g., South China: Brayard \& Bucher, 2008; Primorye, Russia: Shigeta \& Zakharov, 2009; Tulong, Tibet: Brühwiler et al., 2010; Oman: Brühwiler et al., 2012a; Salt Range, Pakistan: Brühwiler et al., 2012b; western USA: Brayard et al., 2013; Jattiot et al., in press). In Svalbard (as in the Queen Elizabeth Islands, Arctic Canada), the genus Xenoceltites is associated with Anasibirites and Wasatchites, unlike other Boreal localities (Tozer, 1961; Weitschat \& Lehmann, 1978). At low and middle palaeolatitudes (e.g., China, western USA) it also occurs with the prionitid fauna, but the latest Smithian is represented by an additional zone characterised by the xenoceltitid genus Glyptophiceras (Waagen, 1895), above the prionitid beds. Therefore, while the Boreal Tardus Zone can be easily correlated worldwide, the subdivision of the uppermost Smithian into an Anasibirites / Wasatchites fauna followed by a Glyptophiceras / Xenoceltites fauna cannot be extended to higher palaeolatitudes (Brühwiler et al., 2010). The separation between Xenoceltites and Glyptophiceras is still unclear - whether the latter is an evolutionary transitional form or an example of intraspecific variation is still a matter of debate (H. Bucher, pers. comm. to V.P., 2017).
The occurrence of the arctoceratid genus Arctoceras Hyatt, 1900 in Svalbard has long been controversial in the literature. According to various authors (e.g., Kummel, 1961; Tozer \& Parker, 1968), it ranges through the whole of the Smithian in Svalbard. It was designated as an index taxon by Korčinskaja (e.g., 1986) to define a new zonation, which was, however, not confirmed by Weitschat \& Dagys (1989). Instead, they retained the classic two-zone scheme (Romunderi and Tardus) for the Smithian in Svalbard. Nevertheless, Weitschat \& Lehman (1978) stated that Arctoceras does range up into the Tardus Zone, whereas Weitschat \& Dagys (1989) did not confirm the presence of arctoceratids in the late Smithian.

\section{Material, location and stratigraphy}

The ammonoid fauna discussed here was collected by the late Wolfgang Weitschat (University of Hamburg) from a single carbonate concretion in a horizon informally known as the 'Fish Niveau' (Wiman, 1910) in the uppermost Lusitaniadalen Member of the Vikinghøgda Formation at Stensiöfjellet (Fig. 2). It corresponds to the ammonoid biostratigraphic level of the Tardus Zone. The material was originally stored in Hamburg, and then

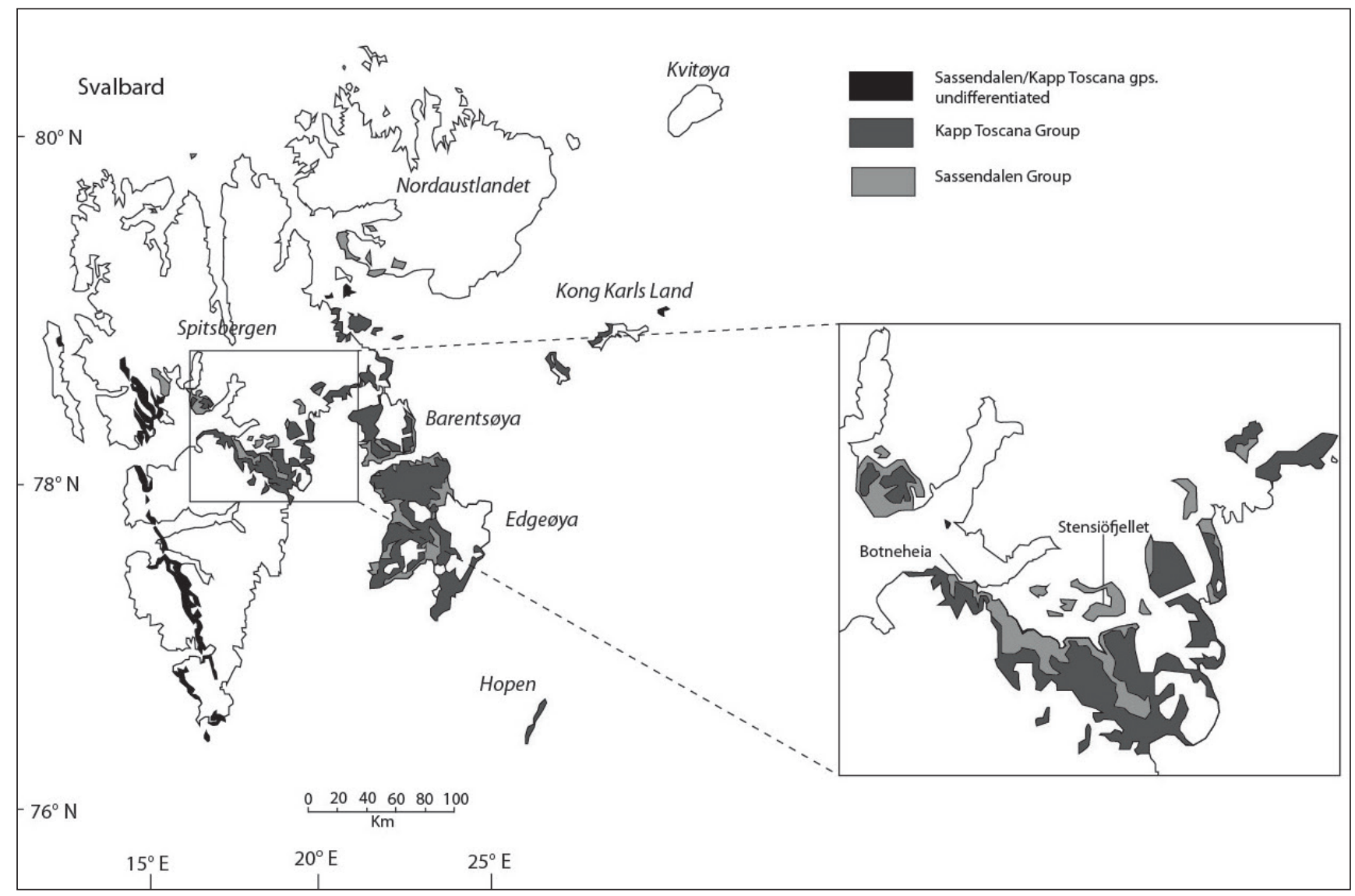

Figure 2. Overview map of the Triassic sedimentary rocks in Svalbard, with an enlarged view of the Sassendalen area. Localities mentioned in text are indicated (modified from Vigran et al., 2014, fig. 10). 
Stensiöfjellet

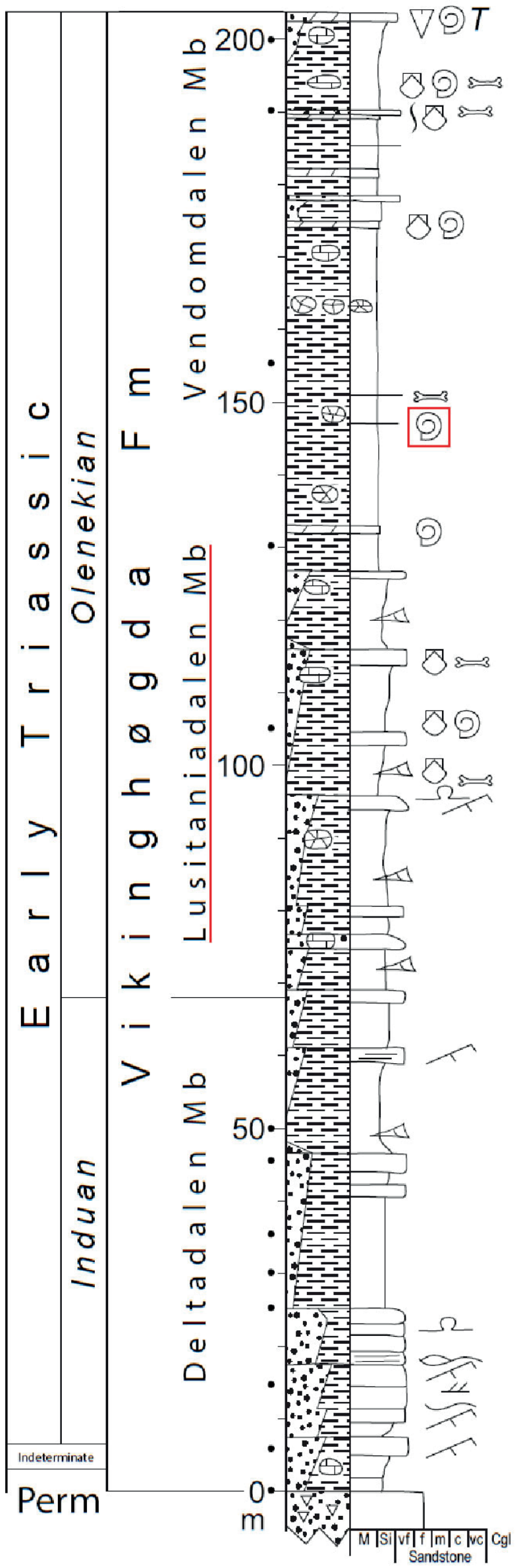

transferred to the Natural History Museum (NHM) in Oslo. Original descriptions of sections and faunas are given by Weitschat \& Lehmann (1978).

The Lusitaniadalen Member (Fig. 3) is composed mainly of dark-grey shales with sandstones, calcareous siltstones and fossiliferous limestone concretions. The sand-/ siltstone content increases in an upward-shallowing trend (Mørk et al., 1999; Lundschien et al., 2014). Carbonate concretions are more prominent in the middle and upper parts, and are most likely of early diagenetic origin (Mørk et al., 1999; Hounslow et al., 2008). The depositional setting is interpreted as a moderately deep shelf environment (Mørk et al., 1999).

\begin{tabular}{|c|c|}
\hline Legend & \\
\hline & Sand- and siltstone \\
\hline & Mudstone/Debris flow \\
\hline & Limestone \\
\hline & Dolomite \\
\hline & Chert \\
\hline & Nodules \\
\hline 8 & Septarian nodules \\
\hline & Calcite cementation \\
\hline & Planar lamination \\
\hline & Hummocky bedding \\
\hline & Lenticular lamination \\
\hline & Ripple lamination \\
\hline & Mud waves \\
\hline 52 & Convolute lamination \\
\hline & Ammonoids \\
\hline & Bivalves \\
\hline 7 & Belemnites \\
\hline$T$ & Tasmanites \\
\hline$\sum=3$ & Vertebrate remains \\
\hline $\int-\int\left(\int\right)$ & Increasing bioturbation \\
\hline
\end{tabular}

Figure 3. Stratigraphic log section of the Vikinghøgda Formation at Stensiöfjellet. The red square represents the concretion horizon from which the studied fauna most likely came (modified from Vigran et al., 2014, figs. 18 \& 38a). 


\section{Methods}

The classical parameters for ammonoid biometry (see e.g., Korn, 2010) were measured: diameter (D), whorl width (W), whorl height $(\mathrm{H})$ and umbilical diameter (U). Ratios of each parameter against corresponding diameter $\mathrm{D}(\mathrm{W} / \mathrm{D}, \mathrm{H} / \mathrm{D}$ and $\mathrm{U} / \mathrm{D})$ were plotted, in addition to the ratio $\mathrm{W} / \mathrm{H}$ to describe the shape of the whorl section. Both absolute values and ratios have been plotted against $\mathrm{D}$ when at least four measurements could be obtained.

The total number of specimens assigned to a genus/ species is labelled as $N$, and the number of measured specimens as $n$.

One specimen described herein (PMO 227.988) was imaged with a Nikon Metrology XT H 225 ST microfocus CT scanner at the Natural History Museum, University of Oslo. The scanning was carried out at $120 \mathrm{kV}, 120 \mathrm{uA}$, $1 \mathrm{~s}$ exposure time, $0.5 \mathrm{~mm}$ tin filter, 3000 rotations.

\section{Results}

The specimens were assigned to nine species. The Xenoceltidae family is represented by a few specimens of Xenoceltites subevolutus (Fig. 4A-B), but the prionitids (Figs. 4C-I, 5, 6A-D) are dominant (Wasatchites tridentinus, Wasatchites cf. distractus, Wasatchites spp. indet., Anasibirites kingianus, Arctoprionites nodosus and Arctoprionites resseri). The group Wasatchites spp. indet. (Fig. 5A-E) includes juvenile specimens of Wasatchites that cannot be identified at the species level. The problematic prionitid Prionitid sp. and the new arctoceratid Arctoceras erebori sp. nov. are discussed below.

The specimens are generally well preserved, with rare evidence of breakage/collapse and diagenetic compression. With some exceptions, no information about the orientation in the concretion is available. The ceratitic suture lines are visible on only a few specimens. The assemblage is composed mainly of immature individuals, as indicated by morphological observations and statistical analyses, with a very similar conch shape but large variation in size, shell coiling and ornamentation among specimens. Ornamentation is thus the key character for taxonomical identification.

The assemblage also provides good material for studying intraspecific variation, as exemplified by Wasatchites (Fig. 5). As intraspecific variation in Triassic ammonoids has been discussed widely in the literature (e.g., Dagys \& Weitschat, 1993b; Weitschat, 2008), we will focus on the implications of the studied assemblage for palaeogeography and biostratigraphy.

\section{Discussion}

The studied fauna is in good agreement with other late Smithian assemblages worldwide, and is most closely related to the Sverdrup Basin among all Boreal regions. Xenoceltites is associated with Wasatchites, confirming previous such reports (e.g., Weitschat \& Lehmann, 1978; Weitschat \& Dagys, 1989). However, the fauna is also characterised by species that have not been previously recorded from Svalbard.

Arctoprionites resseri, for instance, has been recorded in British Columbia and in the USA (Tozer, 1994; Brayard et al., 2013; Jattiot et al., in press). This find suggests a broader palaeogeographic range for this taxon than previously thought, and confirms the faunal similarities between the Svalbard Early Triassic and the Canadian regions, as also highlighted by the presence of Arctoprionites nodosus, which is only known from Arctic Canada outside Svalbard, its type locality (Frebold, 1930; Tozer, 1994).

Similarly, the occurrence of specimens similar to Wasatchites distractus, common in the Tethyan Realm but unknown at higher latitudes, strengthens the cosmopolitan composition of the late Smithian ammonoid faunas. This species is generally recorded from regions such as Salt Range, Spiti and Tibet, where the lower part of the Boreal Tardus Zone is represented by the Wasatchites distractus beds (Brühwiler et al., 2012b; Brayard et al., 2013).

The occurrence of arctoceratids in this level is also worth noting. Findings of Arctoceras erebori sp. nov. at Stensiöfjellet confirm the range of this genus up to the uppermost Smithian, as suggested by e.g., Kummel (1961) and Weitschat \& Lehmann (1978), with Arctoceras erebori sp. nov. possibly restricted to the Tardus Zone.

The lack of additional well-preserved specimens of the taxon Prionitid sp. hinders a more definite taxonomic classification as well as a discussion of its potential palaeogeographic significance.

As Wasatchites cf. distractus and specimens comparable to Prionitid sp. have not been recorded in the Canadian regions, two questions arise: whether the Svalbard fauna may be distinctive, and therefore the erection of a distinct Svalbardian Province (Weitschat \& Dagys, 1989) should be reconsidered, or whether a sampling bias should be taken into account. Further evidence is therefore needed. 

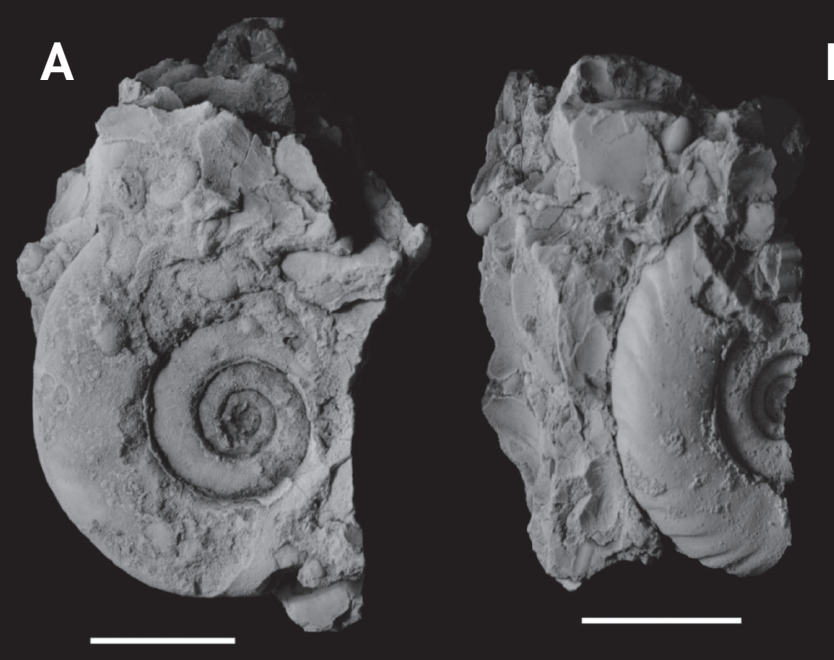

\section{B}

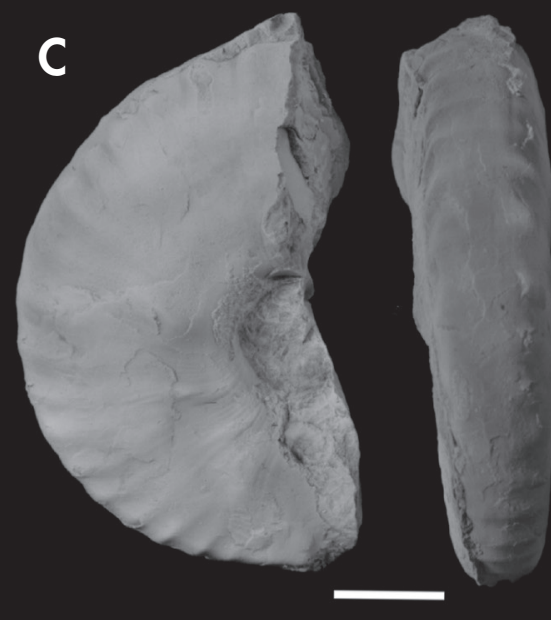

D

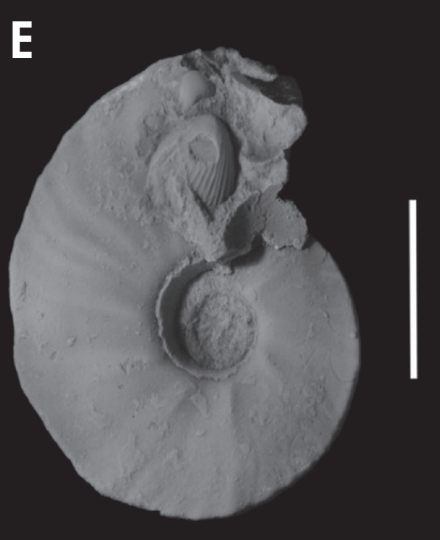

$\mathbf{F}$
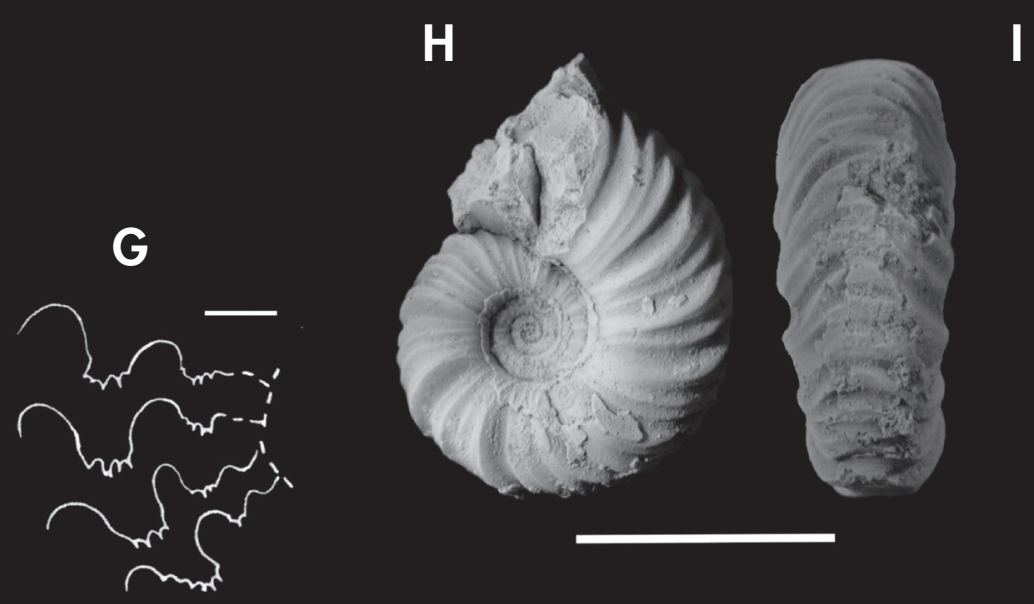

Figure 4. (A-B) Xenoceltites subevolutus Spath, 1930: (A) PMO 227.993. Smooth variant, (B) PMO 227.979. Note constrictions high on flank and crossing venter; (C-D) Arctoprionites resseri (Mathews, 1929): PMO 228.002; (E) Arctoprionites nodosus (Frebold, 1930): PMO 227.991; (F-I) Anasibirites kingianus (Waagen, 1895): (F-G) PMO 227.998. Scale bar for the suture lines = $25 \mathrm{~mm},(H-I) P M O 227.980$. 


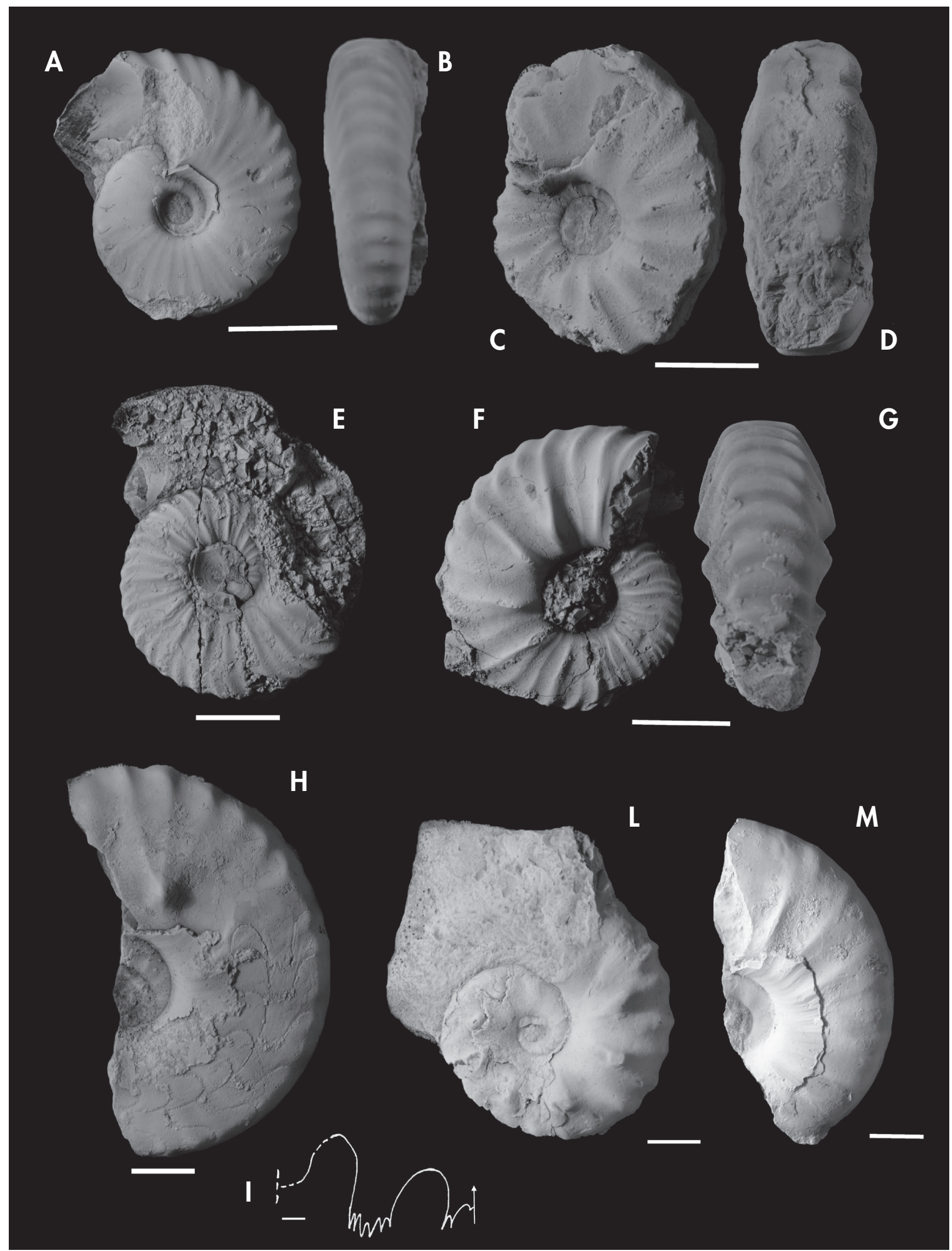

Figure 5.(A-E) Wasatchites spp. indet. Specimens are classified as juvenile/immature stages of Wasatchites because they bear either faint tubercles or none at all: (A-B) PMO 228.012, (C-D) PMO 228.000, (E) PMO 228.011; (F-I) Wasatchites tridentinus Spath, 1934. The not fully mature individual $(F-G)$ still has defined ribbing, which becomes weaker on adult stage (H-I): (F-G) PMO 228.009, (H-I) PMO 228.010. Scale bar for the suture lines $=25 \mathrm{~mm} ;(L-M)$ Wasatchites $c f$. distractus (Waagen, 1895): (L) PMO 228.004, (M) PMO 228.003. Smooth variant. 


\section{Conclusions}

The studied fauna, most of which is characterised by a few cosmopolitan prionitid genera (Wasatchites and Anasibirites being the most common), is in good agreement with other faunas from the Tardus Zone worldwide. These results also strengthen correlations between Svalbard and the Canadian regions, as well as between palaeolatitudes. The concretion described here also provided new insights that are of importance for Early Triassic ammonoid taxonomy, biostratigraphy and palaeogeography:

- Low-latitude ammonoid taxa such as Wasatchites cf. distractus, which until now has not been reported from any Boreal locality, and Arctoprionites resseri, recorded from British Columbia and USA but new in Svalbard, suggest faunal exchange between Svalbard and the Tethys to a higher degree than previously thought. These occurrences improve the correlation between palaeolatitudes.

- The presence of arctoceratids at this level confirms the range of the genus Arctoceras up to the Tardus Zone in Spitsbergen, as already suggested in some previous reports. This is not the first late Smithian occurrence of taxa known from middle Smithian strata. Jattiot et al. (2015) recorded two specimens of Galfettites omani Brühwiler \& Bucher (2012a) in a late Smithian fauna from Noe Tobe, Timor, representing the first and youngest known occurrence of this taxon. Another arctoceratid, Churkites Okuneva, 1990, occurs in the latest middle Smithian in the western USA, but also in the latest Smithian in South Primorye (Shigeta \& Kumagae, 2015). This may indicate that the late Smithian extinction was more gradual than was initially thought.

- The problematic Prionitid sp., which could not be assigned with certainty to any known taxon of the same family, may be evidence of an even higher early late Smithian diversification of the prionitids. On this matter, further investigation might show whether the niches vacated by other families stimulated the radiation of the prionitids.

\section{Taxonomical descriptions}

\author{
By Veronica Piazza.
}

All taxonomical work was conducted with reference to the manual 'Procedure in Taxonomy' (Schenk et al., 1956). The scale bar is $1 \mathrm{~cm}$, unless indicated. The repository of the labelled specimens is abbreviated as PMO (Palaeontological collections of the Natural History Museum, University of Oslo, Norway). Background data are provided in a thesis by the first author (Piazza, 2015).

Class Cephalopoda Cuvier, 1797

Subclass Ammonoidea Zittel, 1884

Order Ceratitida Hyatt, 1884

\section{Superfamily Meekoceratoidea Waagen, 1895}

\section{Family Prionitidae Hyatt, 1900}

\section{Prionitid sp.}

Figs. 6A-D, 7.

Occurrence. Rare in the whole assemblage, $N=6$.

Description. Involute discoidal shell with oval whorl section and convex flanks. Venter commonly arched, smooth or presenting slightly arched to straight ventral ribs. Moderately deep and narrow umbilicus with rounded umbilical shoulder and fairly high-angled umbilical wall. Fairly smooth shell; ornamentation consisting of faint sinuous and regularly spaced ribs most visible on the flanks, as observed on Fig. 6B. Possible constriction observed on the body chamber of specimen PMO 227.988 (Figs. 6C-D, 7). Smooth/slightly ribbed inner whorls. Fairly straight growth lines, although somewhat arched on the venter (Fig. 6A). Poorly preserved ceratitic suture lines, with elongated lobes, broad rounded saddles and denticulated ventral lobes (cf., Fig. 7).

Measurements. See Table 2. Estimated maximum diameter out of $n=3: \sim 27 \mathrm{~mm}$.

Discussion. This taxon is assigned to the family Prionitidae due to the striking, shared characters: compressed shell, narrow umbilicus with rounded umbilical shoulder and high-angled oblique umbilical wall becoming steeper towards the body chamber. The specimens differ from Arctoprionites (Frebold, 1930) and Hemiprionites Spath, 1929 by their lack of tabulate venter, and from Anasibirites Mojsisovics, 1896 and Wasatchites Mathews, 1929 by the ornamentation style. Specimen PMO 227.988 is the best preserved and likely the most mature specimen. Its internal features were observed through CT scanning, and a very high-quality preservation of the internal septa was revealed (Fig. 7), but no further information on the possible constriction 


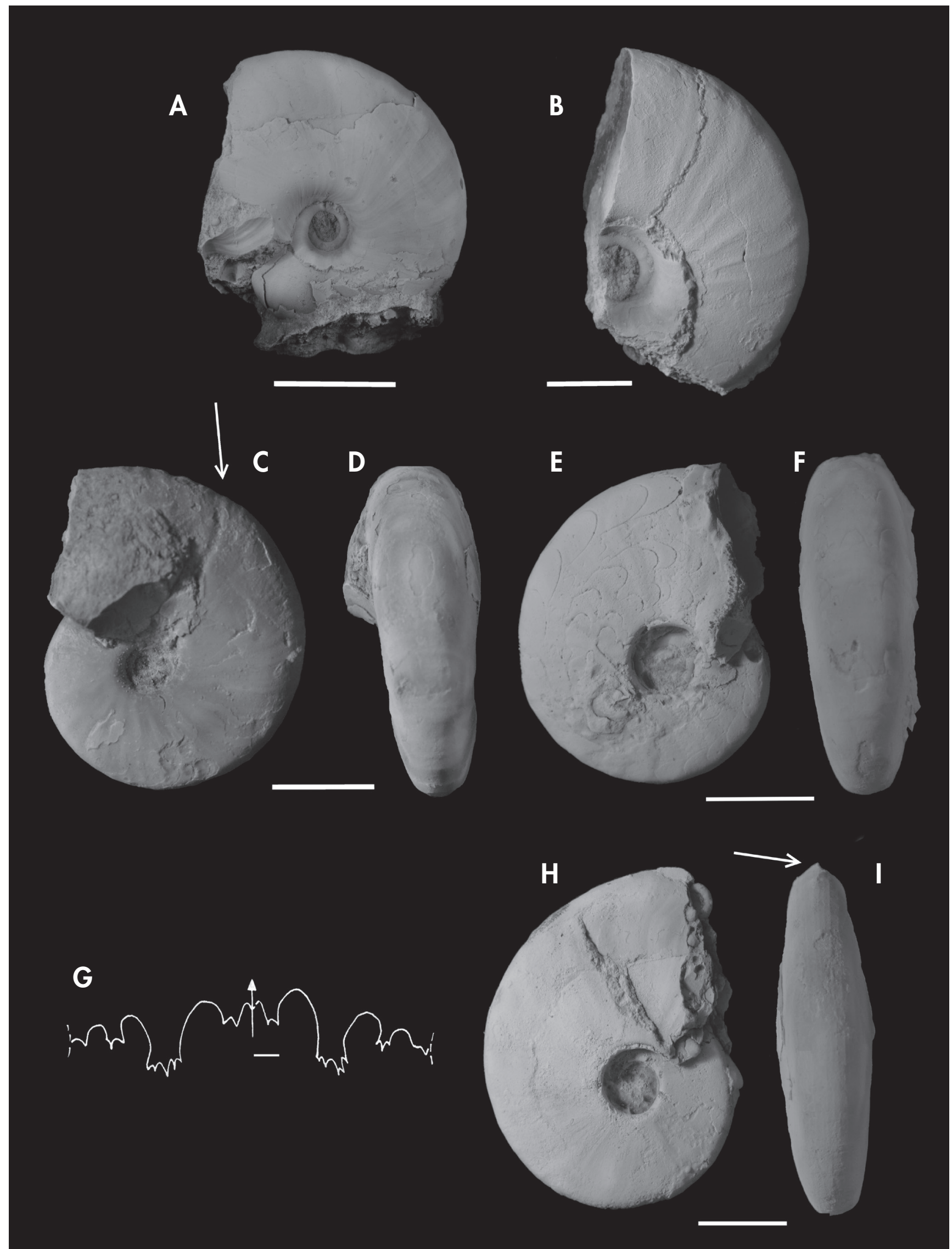

Figure 6.(A-D) Prionitid sp.: (A) PMO 227.987, with the most preserved shell material, (B) PMO 227.989, (C-D) PMO 227.988. The arrow points to the possible constriction; (E-I) Arctoceras erebori sp. nov.: (E-G) PMO 227.985. Drawing of penultimate suture line. Scale bar $=25$ $\mathrm{mm},(\mathrm{H}-\mathrm{I})$ PMO 210.489. Note the keel-like structure and ventral strigation. 
Table 2. Measurements for Prionitid sp.

\begin{tabular}{|c|c|c|c|c|c|c|c|}
\hline $\mathrm{D}$ & $\mathrm{H}$ & W & $\mathrm{U}$ & $\mathrm{H} / \mathrm{D}$ & $\mathrm{W} / \mathrm{D}$ & $\mathrm{U} / \mathrm{D}$ & $\mathrm{W} / \mathrm{H}$ \\
\hline 27.1 & 13.93 & 8.88 & 5.82 & 0.51 & 0.33 & 0.21 & 0.64 \\
\hline 18.29 & 8.5 & 6.03 & 4.23 & 0.46 & 0.33 & 0.23 & 0.71 \\
\hline 26.68 & 14.3 & - & 5.62 & 0.54 & - & 0.21 & - \\
\hline
\end{tabular}

could be obtained. Therefore, this feature cannot be interpreted as a constriction or healed wound with any degree of certainty. If it is a constriction, it may be unique to this prionitid, as such features have not been reported in other prionitids. The CT scanning analysis revealed that the inner whorls are filled with high X-ray density material (probably barite), and the septa are not visible in this region. The other collected specimens of Prionitid sp. do not show such unusual X-ray preservation.

The most difficult comparison has been with the genus Anasibirites. As discussed in the recent revision by Jattiot et al. (2015), this genus can be identified by its distinctive megastriae, which are ridge-like structures generated by discontinuities in secretion of the shell. Megastriae are asymmetric, superficial features, while ribs on the contrary are more symmetric and their formation also involves the deeper mantle layers. Specimens here described do not present megastriae, and possess smooth to slightly ribbed inner whorls. Thus, Prionitid sp. is not comparable to A. kingianus.

Because of the uncertainty of the assignment of our specimens to known prionitid taxa, the possibility of a new taxon has been considered. However, the lack of additional well-preserved material with new diagnostic features has led to an open classification.
Family Arctoceratidae Arthaber, 1911

Genus Arctoceras Hyatt, 1900

Type species. Ceratites polaris Mojsisovics, 1896

\section{Arctoceras erebori sp. nov.}

Fig. 6E-I.

Holotype. PMO 210.489 (Fig. 6H-I).

Paratype. PMO 227.985.

Derivation of name. Named after Erebor, the Lonely Mountain in J.R.R. Tolkien's The Hobbit.

Diagnosis. Arctoceratid with arched venter and slightly convex flanks. The ornamentation consists of weak, radial/gently sinuous folds that cross the flanks but not the periphery. They are irregularly spaced and increasingly distanced towards the body chamber. Ventral strigation present only on specimen PMO 210.489 .

Material. The species is rare in the assemblage, as $N=4$.

Type locality and horizon. Stensiöfjellet, northern Sassendalen, Svalbard. Stratigraphic level: uppermost Lusitaniadalen Member ('Fish Niveau', Vikinghøgda Formation), Tardus Zone ammonoid fauna (late Smithian, Early Triassic).

Description. Subinvolute and extremely discoidal shell with trapezoidal whorl section. Narrow and fairly deep umbilicus with high and very steep (c. $90^{\circ}$ ) umbilical

Table 3. Measurements for Arctoceras erebori sp. nov.

\begin{tabular}{|c|c|c|c|c|c|c|c|}
\hline D & $\mathrm{H}$ & $\mathrm{W}$ & $\mathrm{U}$ & $\mathrm{H} / \mathrm{D}$ & $\mathrm{W} / \mathrm{D}$ & $\mathrm{U} / \mathrm{D}$ & $\mathrm{W} / \mathrm{H}$ \\
\hline 32.29 & 16.92 & 9.91 & 6.63 & 0.52 & 0.31 & 0.21 & 0.59 \\
\hline 28.95 & 13.86 & 9.88 & 6.56 & 0.48 & 0.34 & 0.23 & 0.71 \\
\hline 20.9 & 10.16 & 7.19 & 5.47 & 0.49 & 0.34 & 0.26 & 0.71 \\
\hline 15.91 & 8.05 & 5.16 & 3.43 & 0.51 & 0.32 & 0.22 & 0.64 \\
\hline
\end{tabular}




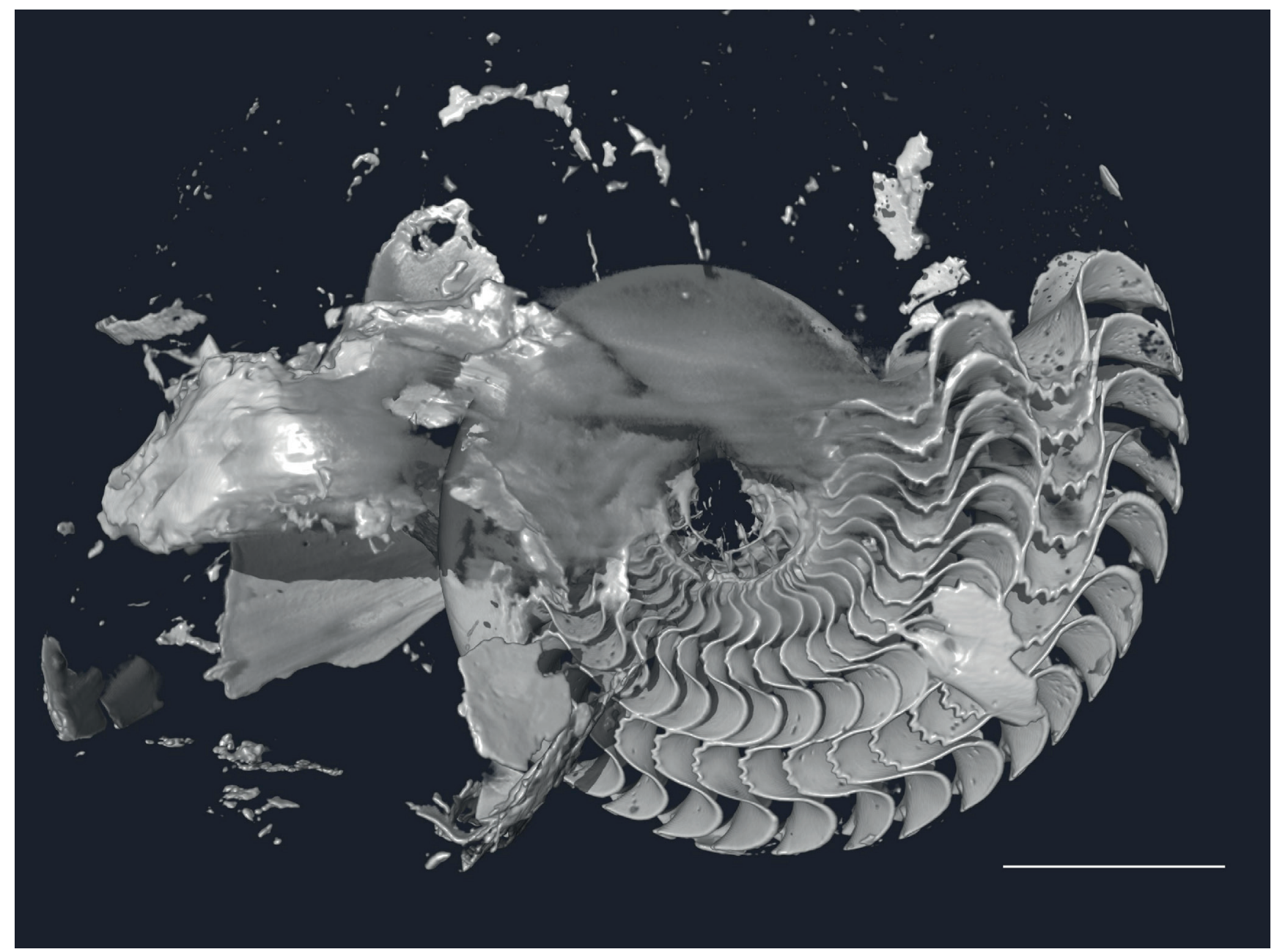

Figure 7. CT scan image of Prionitid sp., PMO 227.988, lateral view, body chamber on top. Outer shell not visible.

wall and sharply angled umbilical shoulder. Venter ranges from arched to broadly rounded. Specimen PMO 210.489 has what appears to be a keeled venter on the terminal part of the preserved body chamber but no ornamentation is visible on the venter other than strigation. Flatter flanks on the more compressed specimens. Further comments on ornamentation are prevented by the poor preservation of the specimens other than holotype. However, radial/gently sinuous folds on the flanks are observed on the best preserved specimens (e.g., PMO 227.985, Fig. 6E-F, which shows finer striae in between the folds). The folds become more distant towards the body chamber. Very well preserved suture lines were found only on specimen PMO 227.985 (Fig. 6G), with two elongated, prominently denticulated lateral lobes and rounded saddles. Denticulation very pronounced with bifurcation on the ventral lobe.

Measurements. See Table 3. Estimated maximum diameter: $\sim 32 \mathrm{~mm}$.

Discussion. The specimens here discussed are assigned to the genus Arctoceras mainly due to the umbilical morphology and to the shape of the venter and whorls. The presence of strigation is not a new feature in the genus, as seen e.g., in A. strigatus Brayard \& Bucher, 2008, where it is most prominent on the flanks, and A. tuberculatum (Smith, 1932); however, both species exhibit clearly different ornamentation. The studied specimens, moreover, bear weaker ornamentation and more irregular and less prominent distance between the folds than in A. blomstrandi (Lindström, 1865), which is the main arctoceratid recorded from the Smithian beds of Spitsbergen. This species (and its synonyms) has never been reported to exhibit a keel at any growth stage. It is possible that this keel-like structure on the holotype's body chamber is simply an artefact of preservation, e.g., compaction fracture.

Arctoceratids are usually a more typical component of middle Smithian faunas. At one locality on Ellesmere Island (Arctic Canada), Arctoceras is associated with Wasatchites (Tozer, 1961). The presence of arctoceratids in this level confirms that the vertical range of Arctoceras extends up into the Tardus Zone, as suggested by previous biostratigraphic research on Smithian faunas in Svalbard, as discussed above. 
Acknowledgements. The late Dr. Wolfang Weitschat (University of Hamburg) is acknowledged for providing the material and suggesting the project. Prof. Hans Arne Nakrem of the Natural History Museum, University of Oslo, and Prof. Dr. Hugo Bucher from the Paleontological Institute and Museum, University of Zürich, are warmly thanked for their useful advice and suggesting improvements in the manuscript.

\section{References}

Arthaber, G. 1911: Die Trias von Albanien. Beiträge zur Paläontologie und Geologie Österreich-Ungarns und des Orients 24, 169-288.

Brayard, A. \& Bucher, H. 2008: Smithian (Early Triassic) ammonoid faunas from northwestern Guangxi (South China): taxonomy and biochronology. Fossils and Strata 55, 1-179.

Brayard, A., Bucher, H., Escarguel, G., Fluteau, F. \& Bourquin, S. 2006: The Early Triassic ammonoid recovery: Paleoclimatic significance of diversity gradients. Palaeogeography, Palaeoclimatology, Palaeoecology 239, 374-395.

https://doi.org/10.1016/j.palaeo.2006.02.003.

Brayard, A., Bylund, K.G., Jenks, J.F., Stephen, D.A., Olivier, N., Escarguel, G., Fara, E. \& Vennin, E. 2013: Smithian ammonoid faunas from Utah: implications for Early Triassic biostratigraphy, correlation and basinal palaeogeography. Swiss Journal of Palaeontology 132, 141-219. https://doi.org/10.1007/s13358-013-0058-y.

Brühwiler, T., Bucher, H. \& Goudemand, N. 2010: Smithian (Early Triassic) ammonoids from Tulong, South Tibet. Geobios 43, 403431. https://doi.org/10.1016/j.geobios.2009.12.004.

Brühwiler, T., Bucher, H., Goudeman, N. \& Galfetti, T. 2012a: Smithian (Early Triassic) ammonoid faunas from exotic blocks from Oman: taxonomy and biochronology. Palaeontographica, Abteilung A 296, 3-107. https://doi.org/10.1127/pala/296/2012/3.

Brühwiler, T., Bucher, H., Ware, D., Schneebeli-Hermann, E., Hochuli, P.A., Roohi, G., Rehman, K. \& Yaseen, A. 2012b: Smithian (Early Triassic) ammonoids from the Salt Range, Pakistan. Special Papers in Palaeontology 88, 1-114.

Cuvier, G.L. 1797: Tableau élementaire de l'Histoire Naturelle des Animaux. Baudouin, Paris, XVI + 710 pp.

Dagys, A. \& Weitschat, W. 1993a: Correlation of the Boreal Triassic. Mitteilungen aus dem Geologisch-Paläontologischen Institut der Universität Hamburg 75, 249-256.

Dagys, A.S. \& Weitschat, W. 1993b: Extensive intraspecific variation in a Triassic ammonoid from Siberia. Lethaia 26, 113-121. https://doi.org/10.1111/j.1502-3931.1993.tb01801.x.

Frebold, H. 1930: Die altersstellung des Fischhorizontes, des Grippianiveaus und des unteren Saurierhorizontes in Spitzbergen. Skrifter om Svalbard og Ishavet 28, 1-36.

Hammer, Ø. \& Bucher, H. 2005: Buckman’s first law of covariation - a case of proportionality. Lethaia $38,67-72$. https://doi.org/10.1080/00241160510013196.

Hounslow, M.W., Peters, C., Mørk, A., Weitschat, W. \& Vigran, J.O. 2008: Biomagnetostratigraphy of the Vikinghøgda Formation, Svalbard (Arctic Norway), and the geomagnetic polarity timescale for the Lower Triassic. Geological Society of America Bulletin 120, 1305-1325. https://doi.org/10.1130/B26103.1.

Hyatt, A. 1884: Genera of Fossil Cephalopoda. Proceedings of the Boston Society of Natural History 22, 253-338.

Hyatt, A. 1900: Cephalopoda. In Zittel, K.A.V. (ed.): Textbook of palaeontology, Eastman, C.R., London, pp. 502-604.

Jattiot, R., Bucher, H., Brayard, A., Monnet, C., Jenks, J.F. \& Hautmann, M. 2015: Revision of the genus Anasibirites Mojsisovics (Ammonoidea): an iconic and cosmopolitan taxon of the late Smithian (Early Triassic) extinction. Papers in Palaeontology 2, 1-34. doi: 10.1002/spp2.1036
Jattiot, R., Bucher, H., Brayard, A., Brosse, M., Jenks, J.F. \& Bylund, K.G. in press: Smithian ammonoid faunas from northeastern Nevada: implications for Early Triassic biostratigraphy and correlation within the western USA basin. Palaeontographica Abteilung A. doi: $10.1127 /$ pala/2017/0070

Korčinskaja, M.V. 1970: Olenekian ammonites of Spitsbergen (Olenekskie ammonity Špicbergena). In Uchenye zapiski. Palaeontologiia i biostratigrafiia, 27, Nauchno-issledovatelskii Institut geologii Arktiki, Leningrad, 80-89 [in Russian].

Korčinskaja, M.V. 1973: Biostratigraphy of Triassic deposits of Svalbard. In Logan, A. \& Hills, L.V. (eds.): The Permian and Triassic systems and their mutual boundary, Canadian Society of Petroleum Geologists 20, pp. 261-268.

Korčinskaja, M.V. 1986: Biostratigraphy of the Induan stage of Spitsbergen. In Geologija osadočnogo čehla Špicbergena (Geology of the sedimentary blanket of the Spitsbergen archipelago). Production-Geological Association Sevmorgeologija, Leningrad, 77-93.

Korn, D. 2010: A key for the description of Palaeozoic ammonoids. Fossil Record 13, 5-12. https://doi.org/10.1002/mmng.200900008.

Kummel, B. 1961: The Spitsbergen Arctoceratids. Bulletin of the Museum of Comparative Zoology at Harvard College 123, 499-523.

Lindström, G. 1865: Om Trias och Juraforsteningar fran Spetsbergen. Svenska Vetenskap-Akademien Handlingar 6, 1-20.

Lock, B.E., Pickton, C.A., Smith, D.G., Batten, D.J. \& Harland, W.B. 1978: The Geology of Edgeøya and Barentsøya, Svalbard. Norsk Polar Institutt Skrifter 168, 1-65.

Lundschien, B.A., Høy, T. \& Mørk, A. 2014: Triassic hydrocarbon potential in the Northern Barents Sea; integrating Svalbard and stratigraphic core data. Norwegian Petroleum Directorate Bulletin $11,3-20$.

Mathews, A.A.L. 1929: The Lower Triassic Cephalopod fauna of the Fort Douglas area, Utah. Walker Museum Memoirs 1, 1-46.

Mojsisovics, E. von 1896: Beiträge zur Kenntniss der obertriadischen Cephalopoden-Faunen des Himalaya. Denkschriften der Kaiserlichen Akademie der Wissenschaften Wien 63, 575-701.

Mørk, A., Dallmann, W.K., Dypvik, H., Johannessen, E.P., Larssen, G.B., Nagy, J., Nøttvedt, A., Olaussen, S., Pčelina, T.M. \& Worsley, D. 1999: Mesozoic lithostratigraphy. In Dallmann, W.K. (ed.): Lithostratigraphic Lexicon of Svalbard. Upper Palaeozoic to Quaternaty bedrock. Review and recommendations for nomenclature use, Norsk Polarinstitutt, Tromsø, pp. 127-214.

Öberg, P. 1877: Om trias-försteningar från Spetsbergen (On Triassic fossils from Spitsbergen). Kungliga Svenska Vetenskapsakademiens Handlingar 14(4). Swedish Royal Academy of Sciences, Uppsala, 19 pp.

Piazza, V. 2015: Late Smithian (Early Triassic) ammonoids from the uppermost Lusitaniadalen Member (Vikinghøgda Formation), Svalbard. MSc thesis, University of Oslo, $135 \mathrm{pp}$.

Schenk, E.T., McMasters, J.H., Keen, A.M. \& Muller, S.W. 1956: Procedure in Taxonomy. $3^{\text {rd }}$ ed. Stanford University Press, Stanford, $119 \mathrm{pp}$.

Shigeta, Y. \& Kumagae, T. 2015: Churkites, a trans-Panthalassic Early Triassic ammonoid genus from South Primorye, Russian Far East. Paleontological Research 19, 219-236. https://doi.org/10.2517/2015PR006.

Shigeta, Y. \& Zakharov, Y.D. 2009: Systematic palaeontologycephalopods. In Shigeta, Y., Zakharov, Y.D., Maeda, H. \& Popov, A.M. (eds.): The Lower Triassic system in the Abrek Bay area, South Primorye, Russia, National Museum of Nature and Science, Tokyo, pp. 44-140.

Smith, J. 1932: Lower Triassic Ammonoids of North America. United States Geological Survey Professional Paper 167, 1-199.

Spath, L.F. 1921: On Ammonites from Spitsbergen. Geological Magazine 68, 297-305. https://doi.org/10.1017/S001675680008907X.

Spath, L.F. 1929: Corrections of cephalopod nomenclature. The Naturalist 871, 269-271.

Spath, L.F. 1930: The Eotriassic invertebrate fauna of East Greenland. Meddelelser om Grønland 83, 1-90. 
Spath, L.F. 1934: Catalogue of the fossil Cephalopoda in the British Museum (Natural History). Part IV - The Ammonoidea of the Trias. The Trustees of the British Museum, London, 521 pp.

Tozer, E.T. 1961: Triassic stratigraphy and faunas, Queen Elizabeth Islands, Arctic Archipelago. Geological Survey of Canada Memoir 316, 116 pp. https://doi.org/10.4095/100543.

Tozer, E.T. 1982: Marine Triassic Faunas of North-America: Their Significance for Assessing Plate and Terrane Movements. Geologische Rundschau 71, 1077-1104.

https://doi.org/10.1007/BF01821119.

Tozer, E.T. 1994: Canadian Triassic Ammonoid Fauna. Geological Survey of Canada, Vancouver, 663 pp. https://doi.org/10.4095/194325.

Tozer, E.T. \& Parker, J.R. 1968: Notes on the Triassic biostratigraphy of Svalbard. Geological Magazine 105, 523-542. https://doi.org/10.1017/S0016756800055886.

Vigran, J.O., Mangerud, G., Mørk, A., Worsley, D. \& Hochuli, P.A. 2014: Palynology and geology of the Triassic succession of Svalbard and Barents Sea. Geological Survey of Norway Special Publication 14, Trondheim, $270 \mathrm{pp}$.

Waagen, W. 1895: Fossils from the Ceratite Formation. Salt Range Fossils, Palaeontologia Indica, Series 13, 1-323.

Weitschat, W. 2008: Intraspecific variation of Svalbardiceras spitsbergensis (Frebold) from the Early Triassic (Spathian) of Spitsbergen. Polar Research 27, 292-297. https://doi.org/10.1111/j.1751-8369.2008.00041.x.

Weitschat, W. \& Dagys, A.S. 1989: Triassic biostratigraphy of Svalbard and a comparison with NE-Siberia. Mitteilungen aus dem Geologisch-Paläontologischen Institut der Universität Hamburg 68, 179-213.

Weitschat, W. \& Lehmann, U. 1978: Biostratigraphy of the uppermost part of the Smithian Stage (Lower Triassic) at the Botneheia, W-Spitsbergen. Mitteilungen aus dem Geologisch-Paläontologischen Institut der Universität Hamburg 48, 85-100.

Wiman, C. 1910: Ichthyosaurier aus der Trias Spitzbergens. Bulletin of the Geological Institution of the University of Uppsala 10, 124-148.

Zittel, K.A.V. 1884: Handbuch der Paläontologie. Mollusca und Arthropoda. Oldenbourg, R., Munich, 839 pp. 